\title{
Why Bother with the Scholarship of Teaching and Learning?
}

\author{
John Draeger, PhD \\ Associate Professor of Philosophy \\ Buffalo State University
}

This paper argues that the scholarship of teaching and learning (SoTL) matters on at least six interrelated levels. First, SoTL matters because learning matters, and SoTL can help students learn more effectively. Second, it offers professors the tools to more effectively share their disciplinary passions. Third, it offers faculty an avenue for continued intellectual growth. Fourth, SoTL can build strong crossdisciplinary communities that enliven the intellectual climate. Fifth, it can inform institutional policymaking. Finally, SoTL matters even when it does not directly transform institutional policy, because SoTL embodies a spirit of pedagogical innovation that enlivens the quest for learning and reminds us why it is worth pursuing.

I discovered Plato's dialogues in my first semester of college. I quickly became a philosophy major because I was enthralled by the nature of big ideas (e.g., truth, justice, and beauty). I went into academia because I dreamed of long afternoons, hunched over a great book. Although my professional reality is somewhat less glamorous, it is true that I get paid to share my passion for philosophy. My introduction to the scholarship of teaching and learning (SoTL) was somewhat less high-minded. A flyer on a bulletin board outside my office announced $\$ 3,000$ fellowships for those interested in engaging something called 'scholarship of teaching and learning.' Since I was trying to buy a house at the time, I reasoned "I am a scholar. I teach. And I really need the money." Years later, I have the house and I am still doing SoTL, though I confess that I am not always sure why. There is only so much time in the day. My choice to do SoTL means that I am choosing not to do other things. There is no question that my scholarly work in philosophy has been impeded by heavy involvement in the scholarship of teaching and learning. Yet, I continue to do it because as I believe and seek to make the case in this paper, SoTL matters.

\section{The Turn Towards Learning}

As a faculty member, I often look out on a classroom full of students and wonder whether I am getting through. They smile, nod, and ask questions, but I never quite know whether they are receiving the message that I am trying to send. The scholarship of teaching and learning offers the prospect of learning more about how students learn. It encourages the ongoing and systematic investigation into student learning in hopes that effective practices might be documented and made publically available (Hutchings \& Shulman, 1999; Kreber \& Cranton, 2000; McKinney, 2007). In short, SoTL has the potential to offer me the resources to share my passion for philosophy more effectively. I am not alone: Most professors are passionate about their subject matter (whatever it may be). Most would welcome the opportunity to become more effective, but few know how this is done. SoTL can provide at least some of the answers. SoTL is worth doing, therefore, if it can improve the lives of both faculty and students.

My evolving views about learning are influenced by my life both as a philosopher and as a SoTL scholar. As a philosopher, I love to explore big ideas that are at once omnipresent in our lives and also rarely considered in any depth. For example, many of our most important values conflict with one another. Promoting economic equality can require curtailing individual liberty, democratically 
elected majorities tend to trample minority rights, and loyalty to friends can keep us from being fair to strangers. Philosophy is worth doing, at least in part, because it gives us the resources to reflect on, articulate, explore, and perhaps even navigate such value conflicts. It will come as no surprise that my approach to philosophy influences my approach to teaching. Students in my introductory ethics courses, for example, often come into class believing that the course is about certain types of content (e.g., the pros and cons of abortion, euthanasia, hate-speech, or famine relief). In my view, however, the course is about learning the skills associated with articulating and evaluating conflicts between important ethical values. I hope that students will learn to recognize deep similarity in superficial difference (e.g., recognize the value of liberty across issues). Students can demonstrate their ability to make important connections between big ideas if they can use the philosophical position developed in one "content" debate to answer questions in another (e.g., use the resources found in a discussion of euthanasia to answer questions about hate speech). In this way, I hope that my students will learn how to make connections between important ideas.

As a SoTL scholar, I have come to appreciate the difference between "surface learning" and "deep learning" (Trigwell \& Prosser, 1991; Prosser \& Trigwell, 1999). On a surface learning model, knowledge is seen as discrete bits of information. Learning involves acquiring as many of these bits as possible within a given content area. Education, in this view, involves the transfer of information from teacher to student. Deep learning, by contrast, encourages students to make connections between seemingly disparate bits of knowledge within and across content areas. It is not simply the ability to identify the trees in the forest, but also to recognize that the trees are in an ecosystem affected by various economic policies and patterns of human consumption. Education, in this view, encourages students to develop expanding networks of conceptual connection.

The deep learning view fits my pedagogical proclivities as a philosopher, but my engagement with SoTL work has refined my practice. For example, deep learning is more likely to occur when instructors provide clear expectations (Trigwell $\&$ Prosser, 1991) and when instructors are actively engaged in making conceptual connections in their own work (Prosser, Martin, Trigwell, Ramsden, \& Lueckenhausen, 2005; Prosser, Martin, Trigwell, Ramesden, \& Middleton, 2008). While I have always tried to be clear with my students and have always hoped that I model good habits of mind, this research reminds me that I need to be intentional about things that I take to be obvious (e.g., the fact that I am trying to model the relevant habits of mind). I find that this is especially true with first-year students. All of us need help learning to make conceptual connections, but SoTL scholars suggest that first-year students are less likely to adopt these strategies on their own (Minasian-Batmanian, Lingard, \& Prosser, 2005). Because of my involvement with SoTL, I have been more conscious of the need to scaffold various exercises, especially for first-year students. Such changes have meant that I have had to ease up on "coverage" (Hanstedt, 2012). Because a student's ability to make conceptual connections is more important than any particular bit of content, I am willing to give students additional time to develop these skills even if we don't "get to everything" by the end of the semester. Because of SoTL's influence, my courses now focus on developing the habit of deep learning. If students learn how to learn, then there is some hope that they will continue learning throughout their lives. This is in accord with my broader view of education (Draeger \& Price, 2011). Higher education must be dedicated to helping students forge meaningful connections between seemingly disparate fields of inquiry (Cronon, 1998) and promoting lifelong learning (Cropley \& Knapper, 1983).

\section{Looking Closely and Critically at Learning: Just-in-Time Teaching}

The fact that I am committed to deep learning strategies does not always mean that I know how to help students develop integrative habits of mind (Huber, Hutchings, \& Gale, 2005). My involvement with SoTL, however, has me on the 
lookout for possible solutions. For example, philosophy students (not unlike students in other disciplines) often struggle to understand the basics of a given reading assignment even before they can begin to integrate it into larger wholes. In 2008, a colleague in the philosophy department at Buffalo State, Jason Grinnell, began requiring that students write short (150-word) abstracts of each assigned reading. These assignments help students learn to extract what is most essential from a given text. This understanding (or misunderstanding) structures class discussion. In 2011, I attended a session on Just-in-Time Teaching strategies at the International Society for the Scholarship of Teaching and Learning (Scharff, Rolf, Novotony, \& Lee, 2011). On the Monday morning after the conference, I popped my head into Grinnell's office to say, "what you've been doing has a name. It's called 'just-in-time teaching.' How about we look into it together?"

After conducting a literature review, we began investigating the role of just-in-time writing assignments in four philosophy courses with a total of 140 students participating (Draeger \& Grinnell, 2012). Grinnell continued to ask students to write abstracts while I began asking students to answer two short questions prior to each day's class. Our data supports previous findings in the literature, namely, that just-in-time teaching increases (a) the likelihood that students will complete assigned readings and (b) the understanding of core course concepts (Howard 2004; Novak, Patterson, Gavrin, \& Christian, 1999; Simkins \& Maier 2004). We also found that students changed their approach to the reading and class preparation. They were less likely to skim and more likely to focus on the main ideas. As a result, they reported feeling better prepared for class and better able to contribute to class discussion. Moreover, because instructors were able to review student work prior to class, we were better able to clarify particular misunderstandings and tailor class discussion to student interests and needs. Abstracts encourage students to solidify their understanding of the most essential elements of each text. These serve as anchors as class discussions turn to broader conceptual connections. Asking students to answer particular prompts prior to class encourages students to explore conceptual connections on their own, and class time can be devoted to examining these connections in light of the text. Both strategies support integrative habits of mind.

The arc of this story follows what Laurie Richlin (2011) calls "the ongoing cycle of scholarly teaching and scholarship of teaching." Grinnell's initial forays into using student abstracts exemplify reflective teaching. Through our engagement with the literature, we moved into the realm of scholarly teaching. With our subsequent study, we moved into the realm of scholarship of teaching and learning. Engagement with SoTL gave us opportunities for intellectual growth as both teachers and scholars.

\section{Engaging Institutional Priorities}

Buffalo State was already one of twelve coordinating institutions within the international Carnegie Academy for the Scholarship of Teaching and Learning (CASTL) leadership program by the time I became part of the campus fellowship program. While the value of the SoTL was not universally recognized on campus at the time, it was a program supported by the highest levels of the administration and a program that fostered a growing community of SoTL scholars. Both the international CASTL program and the campus community served as a teaching commons in which ideas could be explored and exchanged (Huber \& Hutchings, 2005). Because the campus incorporated Boyer's expanded definition of scholarship (Boyer, 1990) into the campus's formal policy for rewards and promotion (Albers, 2007), those new to SoTL could contribute to the commons while having some assurance that their work would be recognized. It is also the case that Cheryl Albers, the first director of the campus SoTL program, was tirelessly dedicated to mentoring new scholars. Her mentoring work continues even as she has retired and I have become the director of the SoTL program. 
Without the flyer on the bulletin board and the formal policy acknowledging the value of SoTL, it is unlikely that I would have made it a part of my research program. Without a supportive mentor and a community of scholars serving as role models, it is unlikely that I would have continued the work. As the current director of the program, I work to increase the presence of SoTL on campus in hopes that colleagues will feel supported in that work. Yet, while a supportive infrastructure increases the likelihood that SoTL will happen, it does not in itself explain why SoTL is worth doing. I have already argued that SoTL matters because it can help students learn more effectively and it can provide faculty with opportunities for intellectual growth, but SoTL can also transform the broader campus community.

Albers (2013) decided early on to engage institutional agendas. For example, when our campus began using the National Survey of Student Engagement (NSSE) for purposes of institutional assessment, Albers (then SoTL director) and her advisory committee chose to align SoTL fellowships with the NSSE's major elements (e.g., active and collaborative learning). Because SoTL work focused on institutional priorities, policymakers had some assurance that policy can be informed by data directly relevant to our particular local context. In some ways, SoTL can serve the same function as a vigorous free press. We might think of the community of SoTL scholars as the campus's investigative unit. While not directly related to policymaking and having no explicit policymaking power, SoTL can inform the larger policy conversation. Like a vigorous free press, SoTL matters because it informs the campus community about the challenges and opportunities as well as offers solutions.

In 2009, an attempt to increase student performance on various NSSE indicators became the cornerstone of the institution's formal five-year plan. At the same time, I joined Pixita del Prado Hill, Lisa Hunter, and Ronnie Mahler in forming a cross-disciplinary research group that set out to make sense of one of the areas that the NSSE identified as an area of concern, namely academic rigor. ${ }^{1}$ Through surveys and interviews with faculty, our group identified four overlapping dimensions of academic rigor occurring at a variety of levels (Draeger, del Prado Hill, Hunter, \& Mahler, 2013). In our view, a context is rigorous if students are actively learning meaningful content with higher-order thinking at the appropriate level of expectation. While neither ubiquitous nor a panacea, this model of academic rigor offers multiple points of relevance (e.g., to faculty, students, and institutional policymakers) and provides the resources with which to meet the institutional mandate to boost academic rigor.

In keeping with the tradition of SoTL on our campus, the academic rigor project operates in a teaching commons in which faculty are encouraged to set aside time to reflect on central aspects of their courses and to be purposeful about their choices. SoTL is valuable because it can frame the conversation. If, for example, academic rigor is defined as actively learning meaningful content within higher-order thinking at the appropriate level of expectation, then professors might use the model to clarify their expectations, explore strategies for active learning, or refine their understanding of higher-order thinking. This might lead them to seek out additional SoTL resources or even conduct and engage in SoTL scholarship. Further, SoTL can inform policymaking. Indeed, policymakers have taken note. At the invitation of the provost, we have presented our findings to the college planning council which sets institutional priorities. At the invitation of deans and department chairs, we have presented at a variety of other venues. It is safe to say that SoTL work on academic rigor has been, at least indirectly, part of a number of policy conversations.

In sum, institutional policies recognizing the value of the scholarship of teaching and learning create space for SoTL scholars to investigate critical

\footnotetext{
Note

${ }^{1}$ It is worth noting that each member of the group had participated in the campus SoTL fellowship program.
} 
institutional initiatives. The study of academic rigor, for example, was prompted by an institutional mandate to promote academic challenge. A series of conversations about the project provided the campus community with an opportunity to come together to reflect on how the community might best realize its core values. SoTL matters, in this case, because it fosters a spirit of innovation among a growing number in the academic community, and because it has the potential to influence institutional policy.

\section{Area of Impact, Promise, Challenge: Faculty Learning}

I have argued that the scholarship of teaching and learning offers the prospect of helping students learn more effectively and provides professors opportunities for intellectual growth. The SoTL fellowship program put me in the room with a growing community of scholars looking closely and critically at innovations in learner-centered education. In particular, Albers carefully mentored me through my first project. In those early days, I can remember smiling as we considered how a 'control group' might figure into my 'methodology.' While I was vaguely familiar with these terms, they were foreign to my life as a philosopher. I would later come to realize that social science methodologies are not required to do SoTL work (Chick, 2013). At the time, however, I felt the need to develop a completely new set of research skills. I have even referred to myself as a "twosport athlete" in an attempt to characterize my two very different forms of scholarship.

My involvement with the broad SoTL community provides me with countless opportunities for the sort of integrative learning that I value for my students. Given that the community tends to be cross-disciplinary, no one can hide behind disciplinary jargon or presuppose that others share the same presuppositions based on knowledge of the same literature. As a result, we try to speak and write in ways that are comprehensible to anyone in academe. Personal intellectual growth is often a by-product of my involvement in this community of scholars. This has been especially true of my engagement with scholars in my various collaborations (e.g., academic rigor and just-in-time teaching).

As the director of the SoTL program on campus, my goal is to help faculty think closely and critically about student learning. This is, at least in part, because students are an ever-changing population. It is quite possible that teaching strategies effective ten years ago may no longer meet student needs. SoTL provides us with the resources to update our practice. In many ways, teaching is just learning in another guise. My approach to faculty development is learnercentered: I encourage faculty to not to think about SoTL as a test of their adequacy as teachers, but as an opportunity to explore how students might learn more effectively. My approach is decidedly "big tent" (Huber \& Hutchings, 2005). I am happy to welcome anyone willing to learn a little more about how their students learn, and willing to learn a little more about themselves along the way.

\section{Conclusion}

In the Scholarship of Teaching and Learning Reconsidered: Institutional Integration and Impact, Pat Hutchings, Mary Taylor Huber, and Anthony Ciccone (2011) suggest that:

Undergraduates, even those who complete degrees, are not learning as much or as well as they should. If students are to be adequately prepared for life, work, and civic participation in the twenty-first century, colleges and universities must pay closer attention to the heart of the educational enterprise. What is it really important for students to know and be able to do? How can higher education institutions and their faculty help students get there? The scholarship of teaching and learning brings powerful new 
principles and practices to ground deliberations about these questions in sound evidence and help point the way (pg. 3).

Like any dynamic system, higher education is challenged by an ever-changing world. The scholarship of teaching and learning provides tools for effective and meaningful transformation. In short, SoTL is worth doing because it matters on a variety of interrelated levels.

First and foremost, the scholarship of teaching and learning matters because learning matters. SoTL encourages us to ask questions about how students learn and how they can learn more effectively. Second, most professors are conscientious professionals who love sharing their disciplines with anyone who will listen. SoTL offers these professionals the tools to become more effective at sharing the object of their passion. Third, SoTL matters because professors are lifelong learners. The scholarship of teaching and learning offers another avenue for continued intellectual growth. This can happen as faculty continue to hone their craft as teachers, but also as they move into expanding areas of scholarship. Fourth, SoTL matters because intellectual communities matter. SoTL creates an environment for those interested in enhancing learning environments and provides opportunities for mutual support. Fifth, SoTL matters because policy matters. We all benefit when those in charge of crafting policy are informed by the best evidence available. Like a vigorous free press, SoTL scholars ask tough questions, take the time to gather evidence, and offer informed views. In this way, SoTL can inform policy conversations. Finally, SoTL matters even when it does not directly transform institutional policy, because SoTL reflects a spirit of pedagogical innovation that enlivens the quest for learning and reminds us why it is worth pursuing.

\section{References}

Albers, C. (2007). Developing a shared meaning of scholarship to enable the revision of promotion policy. International J ournal for the Scholarship of Teaching and Learning, 1(1). Retrieved from http://academics.georgiasouthern.ed u/ijsotl/2007_v1n1.htm

Albers, C. (2013). Growing our own understanding of teaching and learning: Planting the seeds and reaping the harvest. In K. McKinney (ed.), The scholarship of teaching and learning: In and across the disciplines. Bloomington: Indiana University Press.

Boyer, E. L. (1990). Scholarship reconsidered. San Francisco, CA: Carnegie Foundation and JosseyBass.
Chick, N. (2013). Difference, privilege, and power in the scholarship of teaching and learning: The value of humanities SoTL. In K. McKinney (ed.), The scholarship of teaching and learning: In and across the disciplines. Bloomington: Indiana University Press.

Draeger, J., del Prado Hill, P., Hunter, L.R., \& Mahler, R. (2013). The anatomy of academic rigor: The story of one institutional journey. Innovative Higher Education (forthcoming).

Draeger, J. \& Grinnell, J. (2011). Bringing just-in-time-teaching to the humanities presented To International Society for the Scholarship of Teaching and Learning. Milwaukee, WI. 
Draeger, J. \& Price, L. (2011). Which way to SoTL utopia? International J ournal for the Scholarship of Teaching and Learning, 5(1). Retrieved from http://academics.georgiasouthern.ed u/ijsotl/v5n1.html.

Cronon W. (1998). Only connect...The goals of a liberal education. The American Scholar, 67(4), 73-80.

Cropley, A., \& Knapper, C. (1983). Higher education and the promotion of lifelong learning. Studies in Higher Education, 8(1), 15-21.

Hanstedt, P. (2012). General education essentials: A guide to college faculty. San Francisco: Jossey-Bass.

Howard J. (2004). Just-in-time teaching in sociology or how I convinced my Students to actually read the assignment. Teaching Sociology, 32, 385-390.

Huber, M., Hutchings, P. and Gale, R. (2005). Integrative learning for liberal education. Peer Review, 7(4), 4-7.

Huber, M.T., \& Hutchings, P. (2005). The advancement of learning: Building the teaching commons. San Francisco: Jossey-Bass.

Hutchings, P. \& Shulman, L. S. (1999). The scholarship of teaching: New elaborations, new developments. Change, 31(5), 1015.

Hutchings, P., Huber, M.T., \& Ciccone, A. (2011). The scholarship of teaching and learning reconsidered: Institutional integration and impact. San Francisco: JosseyBass.

Kreber, C. \& Cranton, P. A. (2000). Exploring the scholarship of teaching. The J ournal of Higher Education, 71(4), 476-495.
McKinney, K. (2007). Enhancing learning through the scholarship of teaching and learning: The challenges and joys of juggling. San Francisco: Jossey-Bass.

Minasian-Batmanian, L., Lingard, J., $\&$ Prosser, M. (2005). Differences in students' perception of learning compulsory foundation biochemistry in health sciences professions.

Advances in Health Sciences

Education, 10(4), 279-290.

Novak, G., Patterson, E., Gavrin, A., \& Christian, W. (1999). Just-in-time teaching: Blending active learning with web technology. Upper Saddle River, NJ: Prentice Hall.

Prosser, M. \& Trigwell, K. (1999). Understanding learning and teaching: The experience in higher education. Society for Research into Higher Education and Open University Press.

Prosser, M., Martin, E., Trigwell, K., Ramsden, P., \& Lueckenhausen, G. (2005). Academics' experience of understanding of their subject matter and the relationship of this to their experiences of teaching and learning. Teaching in Higher Education, 10, 251-264.

Prosser, M., Martin, E., Trigwell, K., Ramsden, P., \& Middleton, H. (2008). University academics' experience of research and its relationship to their experience of teaching. Instructional Science, 36, 3-16.

Richlin, L. (2001). Scholarly teaching and the scholarship of teaching. In C. Kreber (ed.), New directions for teaching and learning: no 86. Scholarship revisited: Perspectives on the scholarship of teaching and learning. San Francisco: Jossey-Bass. 
Scharff, L., Rolf, J. Novotny, S. \& Lee, R. (2011). Factors impacting completion of pre-class assignments (JiTT) in physics, math, and behavioral sciences. In C. Rust (ed.), Improving student learning:

Improving student learning global theories and local practices:

Institutional, disciplinary and cultural variations. Oxford Brookes University, UK.
Simkins S. \& Maier M. (2004). Using just-in-time teaching techniques in the principles of economics course. Social Science Computer Review, 22, 444-456.

Trigwell, K., \& Prosser, M. (1991). Improving the quality of student learning: The influence of learning context and student approaches to learning on learning outcomes. Higher Education, 22, 251-266.

John Draeger is an Associate Professor of Philosophy and the Director of Scholarship of Teaching and Learning at SUNY Buffalo State. He teaches courses in ethics and philosophy of law. His recent work in philosophy has focused on the nature of respect for persons. His recent SoTL work has focused on topics relating to general education. 